\title{
Reactivation mechanism of ancient giant landslides in the tectonically active zone: a case study in Southwest China
}

\author{
Yongshuang Zhang $\cdot$ Changbao Guo $\cdot$ \\ Hengxing Lan $\cdot$ Nengjuan Zhou $\cdot$ Xin Yao
}

Received: 9 April 2014/ Accepted: 12 February 2015/Published online: 25 February 2015

(C) Springer-Verlag Berlin Heidelberg 2015

\begin{abstract}
The reactivation mechanism and stability of ancient landslides are the major concerns in the tectonically active zone. A detailed case study has been conducted to examine the reactivation mechanism of ancient landslides in Southwest China by investigating the reactivation process, shear strength and stability. Field investigation suggests that the reactivation of ancient giant slides, such as the Luosiwan slide, is attributed to the cumulative effect of adverse geological, structural condition and intensive artificial processes. However, long-term observation has shown that the ancient giant landslides usually remain stable in the remote area in spite of such adverse conditions. Ring shear tests also indicate high peak shear strength of the sliding zone soils. However, the shear strength decreases significantly once displacement occurs at the toe of giant landslide due to engineering construction. The construction process could be considered as the critical triggering factor for the reactivation of ancient giant landslide, which exerts sudden changes in the forces acting on the slope. Both longterm adverse geological evolution and sudden change in the strength lead to the reactivation of giant landslide. This study also suggests that liquefaction plays an important role in the failure behavior of reactivated ancient landslide. An
\end{abstract}

Y. Zhang $(\bowtie) \cdot$ C. Guo $\cdot$ N. Zhou $\cdot$ X. Yao

Key Laboratory of Neotectonic Movement and Geohazard, Ministry of Land and Resources, Beijing 100081, China e-mail: zhys100@hotmail.com

Y. Zhang $\cdot$ C. Guo $\cdot$ N. Zhou $\cdot$ X. Yao

Institute of Geomechanics, Chinese Academy of Geological Sciences, Beijing 100081, China

H. Lan

Institute of Geographic Sciences and Natural Resources Research, Chinese Academy of Sciences, Beijing 100101, China effective drainage system has to be set up during engineering construction so as to reduce the probability of reactivation of ancient landslides.

Keywords Sliding zone soil · Ring shear test · Liquefaction $\cdot$ Stability $\cdot$ Active fault

\section{Introduction}

Ancient giant landslides distributed in the tectonically active regions, such as Southwest China, were often triggered by ancient strong earthquakes. The adverse tectonic conditions and weak rock mass structures are the major factors for their occurrence (Dai et al. 2005; Weidinger 2006; Huang 2009; Futalan et al. 2010; Youssef et al. 2012; Papadopoulou et al. 2013). Since then, subsequent events, such as crustal movement, erosion and weathering tend to promote downslope movement. Reactivation of ancient giant landslides is more frequently observed especially in the region with intensive human engineering activities. For example, an ancient landslide was identified by field survey near the Luosiwan Hydropower Station on the Chongjiang River, a tributary of the Jinsha River in Yunnan Province, Southwest China. It is one of the numerous ancient landslides in the upper Jinsha River and in the Sanjiang tectonic active zone (Huang 2009; Weidinger 2006; Dai et al. 2005). It is located near the junction of two branch faults of the Zhongdian active fault zone in Southwest China. Part of the landslide was reactivated due to construction of G214 National Highway crossing its toe, which poses threats to the safety of both G214 National Highway and the Luosiwan Hydropower Station. The reactivation mechanism and stability of such ancient giant landslides are the major concerns in the tectonically active zone. 
Generally, seldom can the reactivation of a slide be attributed to a single cause. It is a complex process involving geomorphological, physical and artificial processes (Varnes 1978; Cruden and Varnes 1996; Bathrellos et al. 2012, 2013). Nevertheless, reactivated landslides generally move along pre-existing shear planes, where strength parameters approach residual (Skempton 1970) or ultimate (Krahn and Morgenstern 1979) values. The firsttime slides on whose rupture surfaces, resistance to shear may initially approach peak values (Hutchinson 1988). Some ancient landslides occurred even before Holocene in Southwest China. The properties of rupture surface may have changed significantly since then. The activity of reactivation may also be distinguished from the first-time movement. The changes may reflect the influence of longterm environmental conditions on the stability of ancient slides (Youssef and Maerz 2013).

A series of field investigations have been conducted since 2009 on the ancient Luosiwan landslide, from a view of the whole slide to the local reactivated movement. The aim of this paper is to examine the reactivation mechanism of the ancient Luosiwan landslide by analyses on its geomorphological process, shear behavior of sliding zone and stability. The research results are helpful to recognize reactivation mechanism of ancient giant slides and their stability, and instructive to landslide hazard control in the tectonically active zone, particularly in Southwest China.

\section{Geological background}

\section{Geological conditions}

The Luosiwan landslide is a giant ancient landslide identified during field survey near the Luosiwan Hydropower Station on the Chongjiang River, a tributary of the Jinsha River (Fig. 1). It is located at the right bank of the Chongjiang River. Like many other ancient landslides in this region, it occurred near the junction of two branch faults of the Zhongdian active fault, a most favorable place for development of giant landslides (Martel 2004; Zhang et al. 2007, 2011b, c). It mainly consists of Middle Triassic slate intercalated with limestone and green schist $\left(\mathrm{T}_{2} a\right)$, Upper Permian meta-basalt and volcanic breccia intercalated with green schist $\left(\mathrm{P}_{2} b\right)$. These strata were formed in varying orientations: on the whole, downslope dipping on the back edge and upslope dipping or obliquely dipping on the front edge, with a dip angle in a range of $40-60^{\circ}$. The elevation of the back edge is at about $3500 \mathrm{~m}$ and that of the front edge is at $2450 \mathrm{~m}$. The Luosiwan landslide is in a semi-circle planar form. Its volume is roughly estimated to be about $5.8 \times 10^{8} \mathrm{~m}^{3}$.
Characteristics of the reactivated slide

The right bottom of the Luosiwan landslide has been reactivated, which is called a secondary landslide (Figs. 2a, b and 3). Evidences during field survey show that the movement of secondary landslide tends to accelerate. It is in a narrow long tongue shape and its toe is close to the Chongjiang River. The secondary landslide is $800 \mathrm{~m}$ long and $350 \mathrm{~m}$ wide, with an estimated volume of $300 \times 10^{4} \mathrm{~m}^{3}$. The elevation of the back edge is at $2780 \mathrm{~m}$ and that of the front edge is at 2450-2485 m. It is a deep-seated landslide and the surface of rupture is over $50 \mathrm{~m}$ deep.

The sliding mass consists mainly of Upper Permian basalt (basaltic slate) intercalated with schist. Most of them are upslope dipped or obliquely dipped. The overall bedding orientation is $290^{\circ} \angle 38^{\circ}$. The major sliding direction is $355^{\circ}$, nearly perpendicular to the flow direction of the Chongjiang River.

The secondary landslide is bounded by a small gully on the west and by steep steps on the east. The chair-shaped back scarp is 15-35 m high. The middle part of it appears in a stepped form. The overall dip angle of the rupture surface is about $22^{\circ}$. The front edge is a $50-\mathrm{m}$ high steep cut slope. Two sets of joints can be identified in the fractured rock mass at the front edge: One is $134^{\circ} \angle 49^{\circ}$ in orientation and $2-3 / \mathrm{m}$ in joint density; another is $43^{\circ} \angle 64^{\circ}$. The two sets of joints are conjugated and tend to develop into downslope sliding planes.

Engineering construction activities have been considered as the major factors for landslide reactivation, such as pavement excavation during construction of the Luosiwan Hydropower Station and expansion of G214 National Highway after completion of the dam. Obvious deformation has been developed in the secondary landslide in the past 10 years since the completion of the Luosiwan Hydropower Station. The movement tends to accelerate owing to expansion of G214 National Highway. The embankment and the retaining wall of the front edge have moved $2.5 \mathrm{~m}$ towards the Chongjiang River. During the wet season in 2010, four large tensile cracks were developed at the back edge, which were about $0.5 \mathrm{~m}$ wide and more than $10 \mathrm{~m}$ long. It is shown that the secondary landslide is in creeping state.

\section{Methodology}

Shear strength is a key parameter for stability analysis of landslide. The shear strength of soil is commonly described by two measurable components: the internal frictional angle and the intrinsic cohesion. Both parameters can be measured by performing a series of direct shear tests on soil samples under varying confining pressures. The 
Fig. 1 Locations of the Luosiwan ancient landslide and its secondary landslide 1 -active fault, 2-ancient fault, 3-stratum boundary, 4-topographic contour, 5-landslide, 6-Luosiwan Hydropower Station, 7-water system, 8-planned Yunnan-Tibet railway, 9-G214 National Highway

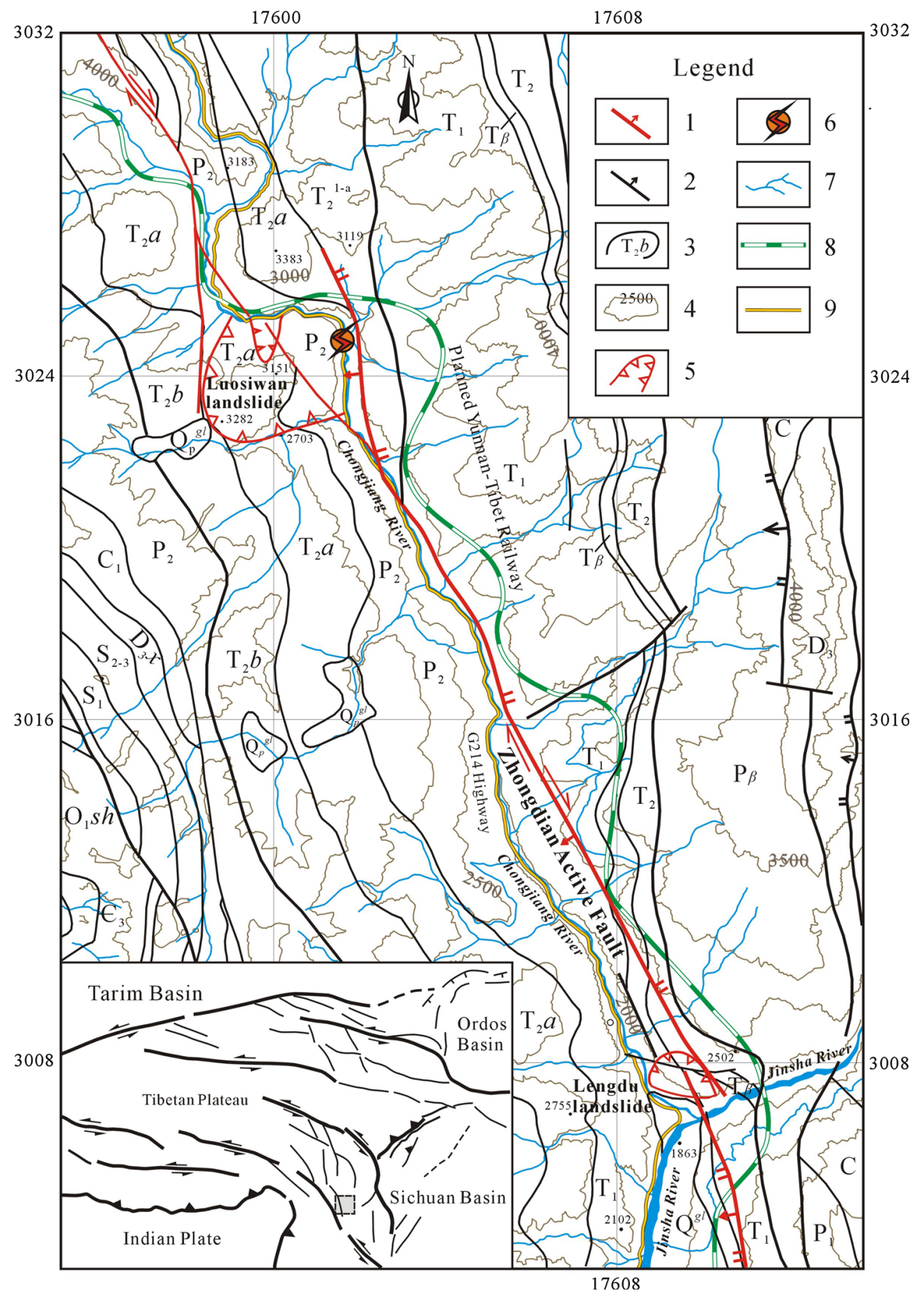

residual strength refers to the minimum shear stress to keep continuous deformation without further increase of shear stress after the specimen reaches the peak strength. The residual shear strength, defined by the post-peak strength behavior of strain-softening materials, is generally assumed to occur during landsliding. According to Skempton (1985), once the shear surface forms, the soil strength is controlled by its residual strength, whatever the type of the soil is. Such strength can be obtained only when shear displacement is relatively large. In the repeated direct shear test, the horizontal shear displacement is limited and the shear area continuously varies. The continuously varying shear area leads to inconstant and heterogeneous normal stress in soil (Dai et al. 1998). The ring shear method, therefore, is adopted to measure the shear strength of sliding zone soil as a large shear displacement is allowed while the shear area and the normal stress can be maintained constant during the test (American Society for 

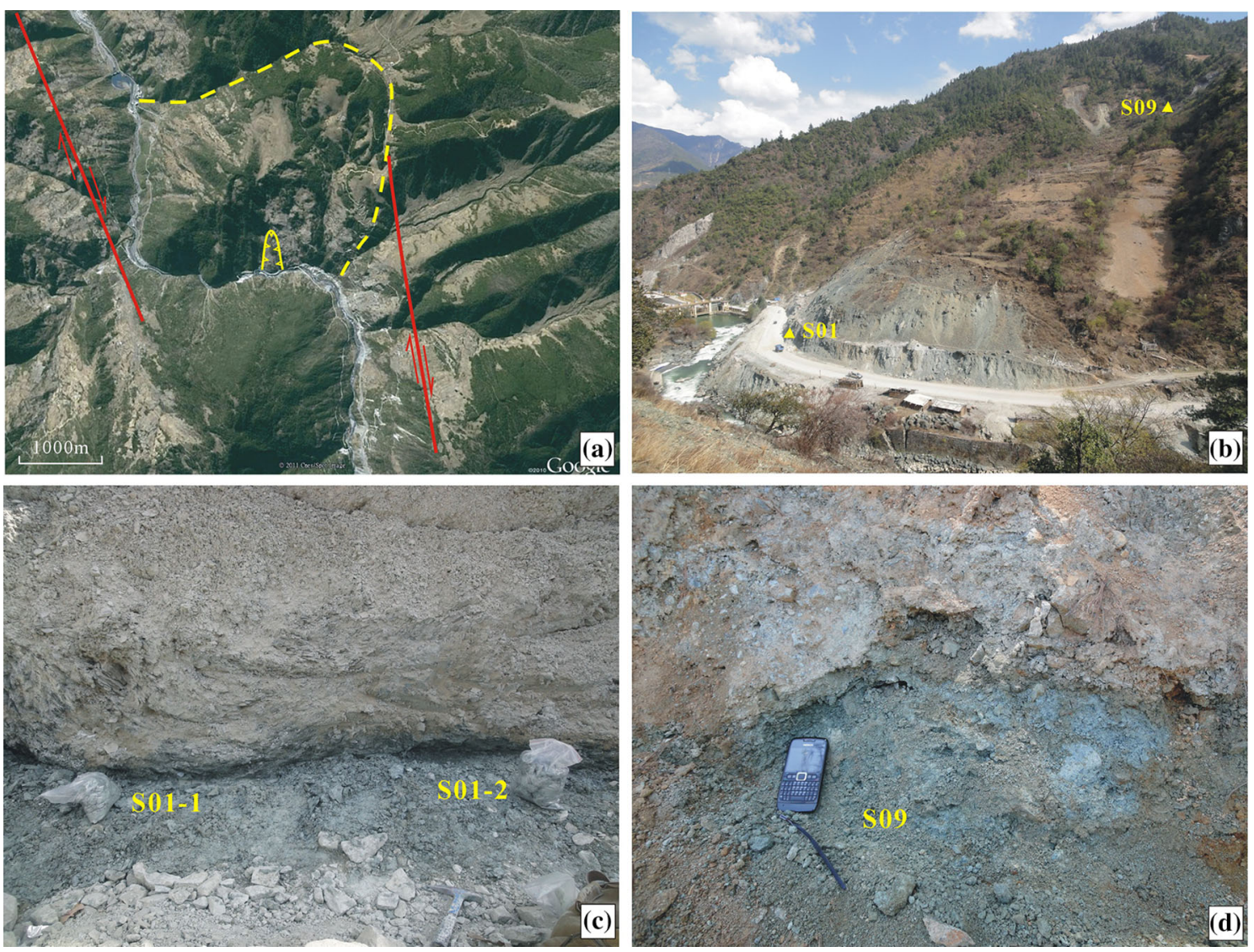

Fig. 2 Characteristics of the Luosiwan landslide and the sliding zone soil of secondary landslide a aerial image of Luosiwan giant ancient landslide (from Google Earth); b the secondary landslide; c shear

plane outcrop and sliding zone soil at the toe of the secondary landslide; d sliding zone soil on the back scarp of the secondary landslide

Testing and Materials 1964; Sassa et al. 2004; Yang et al. 2001). To estimate the residual shear strength of the landslide slip surface. Torsional ring and direct shear tests were performed to investigate the shear behaviors of the sliding zone soil in this study.

\section{Distribution of sliding zone}

Sliding zone soil of reactivated secondary slide was identified mainly on the front and back edges of the secondary landslide. The sliding zone soil of front edge was observed on the roadside slope $0-60 \mathrm{~cm}$ above the pavement. It is generally 30-40 cm thick (Fig. 2c) and has well-developed scratches and obviously oriented debris. The back edge slip soil is exposed near the back scarp of the landslide (Fig. 2d).

Soil samples of sliding zone

Two sets of soil samples, S01 and S09, were collected from the sliding zone (Fig. 2). S09 was taken from the back scarp of secondary landslide. It is generally gray or gray

green and its grain size is relatively coarse due to the dominant tensile behavior at the back scarp area (Fig. 4). The grains with size more than $5 \mathrm{~mm}$ were removed from the test specimens. The natural water content, natural unit weight and dry unit weight of S01 are $5.85 \%, 1.94 \mathrm{~g} / \mathrm{cm}^{3}$ and $1.83 \mathrm{~g} / \mathrm{cm}^{3}$, respectively. S01 was taken within a $30-40 \mathrm{~cm}$ thick sliding zone soil layer at the toe of the secondary landslide. It is generally blue gray, scale-shaped and unctuous with minor debris. Its grain size is relatively fine due to a higher content of clay (Figs. 4 and 5), which is a sign of compression and shear caused by creeping of the landslide. During preparation of test specimens, only a few grains larger than $5 \mathrm{~mm}$ were removed. The natural water content, natural unit weight and dry unit weight of S09 are $9.1 \%, 2.24 \mathrm{~g} / \mathrm{cm}^{3}$ and $2.07 \mathrm{~g} / \mathrm{cm}^{3}$, respectively.

\section{Ring shear test}

Ring shear tests were performed to test the shear strength of soil at the rupture surface. With the DTA-138 soil engineering ring shear apparatus developed by Seiken. Inc., Japan, the following procedures were followed to prepare 


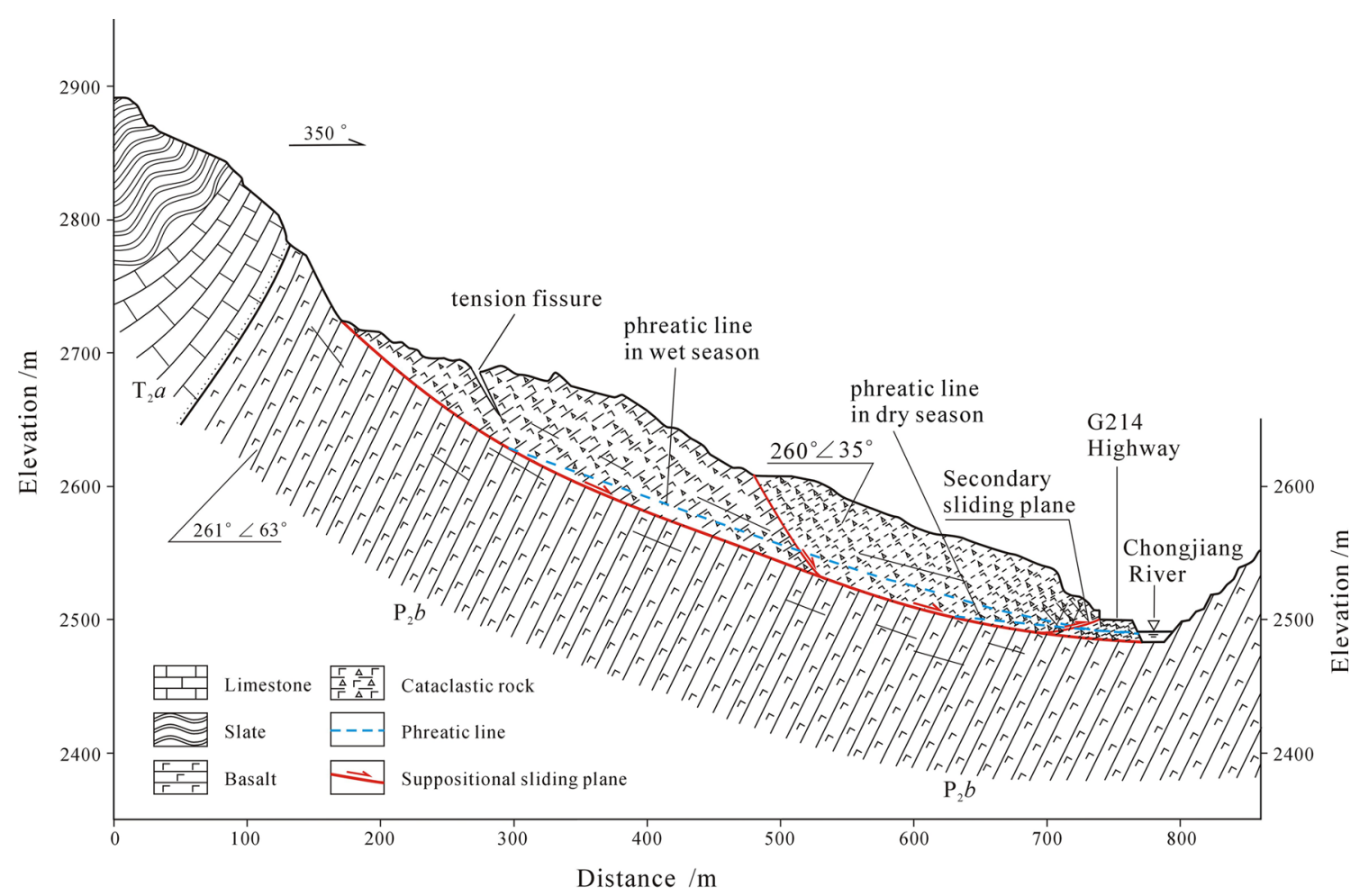

Fig. 3 Geological profile of the Luosiwan secondary landslide

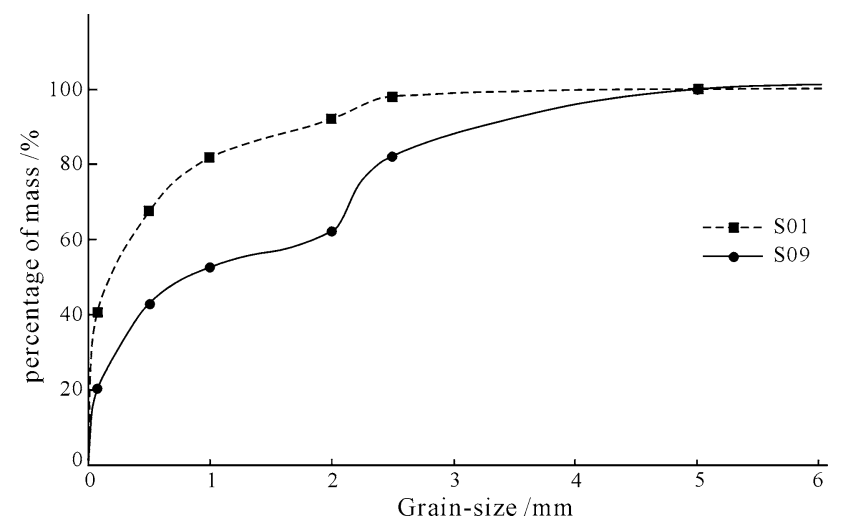

Fig. 4 Grain size distribution curves of sliding zone soil samples S09 and $\mathrm{S} 01$

three tests for each sliding zone soil sample: (1) air is removed from the specimen by $\mathrm{CO}_{2}$; (2) the specimen is saturated in distilled water for four hours; and (3) the specimen is drained and consolidated by vertical loading. The consolidation undrained (CU) ring shear test was then conducted on each specimen under different normal stresses. An effective normal stresses of $100 \mathrm{kPa}$ or less correspond to shallow landslides or shallow portions of a slip surface $(<5 \mathrm{~m})$ (Stark et al. 2005). In this study, experiments were conducted under a normal stress of 100 , 200 , and $400 \mathrm{kPa}$, respectively, corresponding to the deep- seated landslide situation. The twist moment, vertical load, and vertical displacement were automatically recorded every minute during the test. For comparison, the repeated direct shear test and the triaxial CU compression test were also carried out on samples with different water contents.

\section{Test results}

Shear failure

Shear failure was observed in all the specimens under different normal stresses. On one side of the test specimen S01, a shear band, about $3 \mathrm{~mm}$ thick, is formed with obvious local cracks, accompanied by migration and rearrangement of soil grains. The test specimen is separated into two parts along a shear surface. It is worth noting that the specimen after shearing became viscous and difficult to remove from the ring shear apparatus. Some shear planes often show annular trenches with obvious shearing characteristics. Uneven shear bands can also be seen, indicating that soil grains are rearranged with a large displacement along shear surfaces. For example, it is visible that flaky minerals near shear surfaces are rearranged at different levels whose long axes are roughly in line with the shearing direction.

Test specimens (S09) taken from the back edge sliding zone also exhibited obvious shear failure characteristics. 

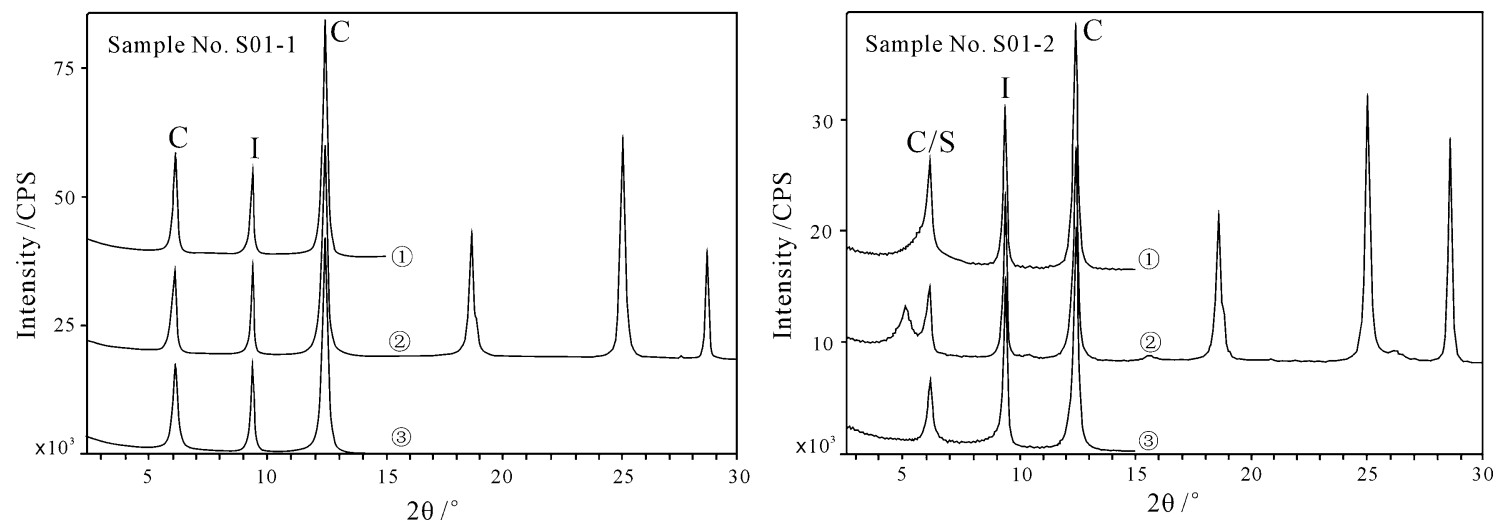

Fig. 5 X-ray diffraction analyses of the $<2 \mu \mathrm{m}$ fraction of soil samples taken from the front edge sliding zone (1)natural sample, (2)glycolsaturated sample, (3)sample heated to $550{ }^{\circ} \mathrm{C}$. C-chlorite, I-illite, $\mathrm{C} / \mathrm{S}$-chlorite/montmorillonite mixed-layer mineral

Table 1 Results of ring shear test on samples S01 and S09

\begin{tabular}{|c|c|c|c|c|c|c|c|c|c|c|}
\hline \multirow[t]{2}{*}{$\begin{array}{l}\text { Sample } \\
\text { no. }\end{array}$} & \multirow[t]{2}{*}{$\begin{array}{l}\text { Sampling } \\
\text { location }\end{array}$} & \multirow[t]{2}{*}{ Density/g. $\mathrm{cm}^{-3}$} & \multirow[t]{2}{*}{$\begin{array}{l}\text { Water } \\
\text { content } / \%\end{array}$} & \multicolumn{3}{|c|}{$\begin{array}{l}\text { Peak strength } \\
\text { under different } \\
\text { normal stress }(\mathrm{kPa})\end{array}$} & \multicolumn{2}{|c|}{ Peak strength } & \multicolumn{2}{|c|}{ Residual strength } \\
\hline & & & & 100 & 200 & 400 & $\begin{array}{l}\text { Cohesion } \\
c_{\mathrm{d}} / \mathrm{kPa}\end{array}$ & $\begin{array}{l}\text { Internal friction } \\
\text { angle } \varphi_{\mathrm{d}}{ }^{\circ}\end{array}$ & $\begin{array}{l}\text { Cohesion } \\
c_{\mathrm{r}} / \mathrm{kPa}\end{array}$ & $\begin{array}{l}\text { Internal friction } \\
\text { angle } \varphi_{\mathrm{r}}{ }^{/}\end{array}$ \\
\hline S01 & Front edge & 2.24 & 9.10 & 67.87 & 122.23 & 241.25 & 11.65 & 29 & 10.67 & 22 \\
\hline S09 & Back edge & 1.94 & 5.85 & 92.65 & 200 & 372.48 & 17.52 & 37.7 & 13.35 & 34.8 \\
\hline
\end{tabular}

Penetrative shear strips can be observed in the middle of the test specimen, while in the contact with the upper pervious part there are tension fissures 1-2 mm wide converged to shear surfaces in the middle part of the test specimen. Similar to S01, it is difficult to remove the test specimen after shearing from the ring shear apparatus. No liquefaction was observed, while water dripping occurs as the specimens were fully saturated. This might be related to the grain size distribution of the back edge sliding zone soil.

\section{Shear strength}

The shear strengths obtained by ring shear tests are listed in Table 1. For comparison, the shear strength obtained by repeated shear tests and triaxial compression tests on the front edge sliding zone soil are listed in Table 2.

Fig. 6a plots the shear stress-displacement curves of the sample S01 under a vertical stress of 100, 200 and $400 \mathrm{kPa}$, respectively. It can be seen that the shear stress of the specimen increases sharply with the increase of shear displacement at the beginning of the test, and then decreases after the peak stress, indicating strain softening. It is suggested that once the creep rate of the secondary landslide increases or large displacement occurs, the shear strength of soil at the toe will decrease rapidly.

Fig. $6 \mathrm{~b}$ plots the peak strength and residual strength envelopes for the sample S01 obtained by linear regression of shear stress vs. vertical pressure plot. From this figure, the internal friction angle $\varphi$ and the cohesion $c$ can be obtained: $\varphi_{\mathrm{d}}=29^{\circ}$ and $c_{\mathrm{d}}=11.65 \mathrm{kPa}$ for the peak strength, while $\varphi_{\mathrm{r}}=22^{\circ}$ and $c_{\mathrm{r}}=10.67 \mathrm{kPa}$ for the residual strength (Table 1).

The shear stress-displacement curve of S09 is shown in Fig. 7a. Apparently, the shear stress almost remains unchanged after the peak strength, which is one of the main differences between S01 and S09. The shear stress-displacement curve of S09 under a high vertical stress is more tortuous than that of S01, because the grains of S09 are coarser, compared to S01.

Similarly, for the sample S09, $\varphi_{\mathrm{d}}=37.7^{\circ}$ and $c_{\mathrm{d}}=17.52 \mathrm{kPa}$ for the peak strength, while $\varphi_{\mathrm{r}}=34.8^{\circ}$ and $c_{\mathrm{r}}=13.35 \mathrm{kPa}$ for the residual strength (Fig. $7 \mathrm{~b}$ and Table 1). The high shear strength of back edge sliding zone soil suggested that the grain size distribution has an obvious influence on the shear behavior.

\section{Discussions}

Strength along a pre-existing shear surface

The residual strength is strongly related to the type of clay mineral and quantity of clay particles. There are wellestablished correlations between the residual shear strength 
Table 2 Results of repeated shear test and consolidated-undrained triaxial compression test on sample S01

\begin{tabular}{|c|c|c|c|c|c|c|c|c|c|c|}
\hline \multirow{3}{*}{$\begin{array}{l}\text { Sample } \\
\text { no. }\end{array}$} & \multirow{3}{*}{$\begin{array}{l}\text { Macroscopic } \\
\text { feature }\end{array}$} & \multirow{3}{*}{$\begin{array}{l}\text { Water } \\
\text { content/ \% }\end{array}$} & \multicolumn{4}{|c|}{ Repeated shear test } & \multicolumn{4}{|c|}{ Consolidation-undrained test } \\
\hline & & & \multicolumn{2}{|c|}{ Slow shear strength } & \multicolumn{2}{|c|}{ Residual strength } & \multirow{2}{*}{$\begin{array}{l}\text { Cohesion/ } \\
\mathrm{kPa}\end{array}$} & \multirow{2}{*}{$\begin{array}{l}\text { Internal } \\
\text { friction } \\
\text { angle } /^{\circ}\end{array}$} & \multirow{2}{*}{$\begin{array}{l}\text { Effective } \\
\text { cohesion/ } \\
\mathrm{kPa}\end{array}$} & \multirow{2}{*}{$\begin{array}{l}\text { Effective } \\
\text { internal } \\
\text { friction angle/ }{ }^{\circ}\end{array}$} \\
\hline & & & $\begin{array}{l}\text { cohesion } \\
c_{\mathrm{d}} / \mathrm{kPa}\end{array}$ & $\begin{array}{l}\text { internal } \\
\text { friction } \\
\text { angle } \varphi_{\mathrm{d}}{ }^{\circ}\end{array}$ & $\begin{array}{l}\text { cohesion } \\
\mathrm{c}_{r} / \mathrm{kPa}\end{array}$ & $\begin{array}{l}\text { internal } \\
\text { friction } \\
\text { angle } \varphi_{\mathrm{r}} /^{\circ}\end{array}$ & & & & \\
\hline \multirow[t]{3}{*}{ S01-1 } & \multirow{3}{*}{$\begin{array}{l}\text { Blue-grey, scaly, } \\
\text { flexible }\end{array}$} & 3.3 & 53.6 & 28.7 & 14.9 & 13.3 & & & & \\
\hline & & 11.8 & 19.3 & 20.0 & 17.3 & 17.9 & & & & \\
\hline & & 17.6 & 14.4 & 19.4 & 11.9 & 16.4 & & & & \\
\hline \multirow[t]{3}{*}{ S01-2 } & \multirow{3}{*}{$\begin{array}{l}\text { Blue-grey, scaly, } \\
\text { flexible }\end{array}$} & 8.1 & 35.6 & 24.0 & 19.8 & 15.5 & 58.5 & 22.4 & 33.0 & 27.2 \\
\hline & & 13 & 31.8 & 16.8 & 26.9 & 11.4 & 32.0 & 21.8 & 21.0 & 27.7 \\
\hline & & 17.3 & 8.0 & 25.0 & 2.5 & 22.1 & & & & \\
\hline
\end{tabular}
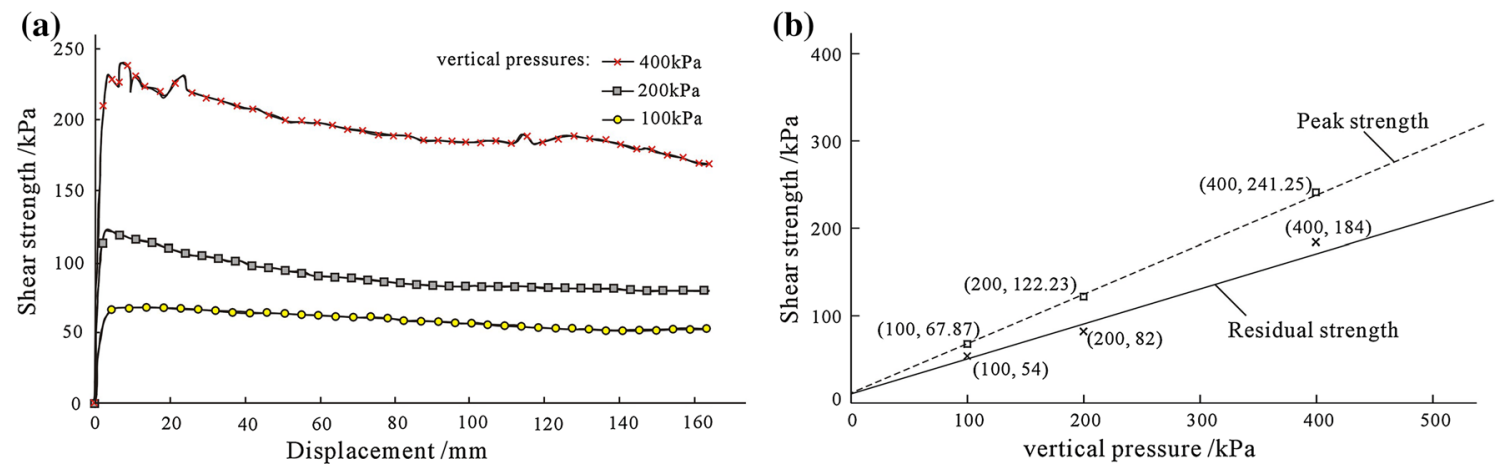

Fig. 6 Shear stress-displacement plots (a) and envelopes of the peak strength and the residual strength (b) for soil samples (S01) taken from the front edge sliding zone
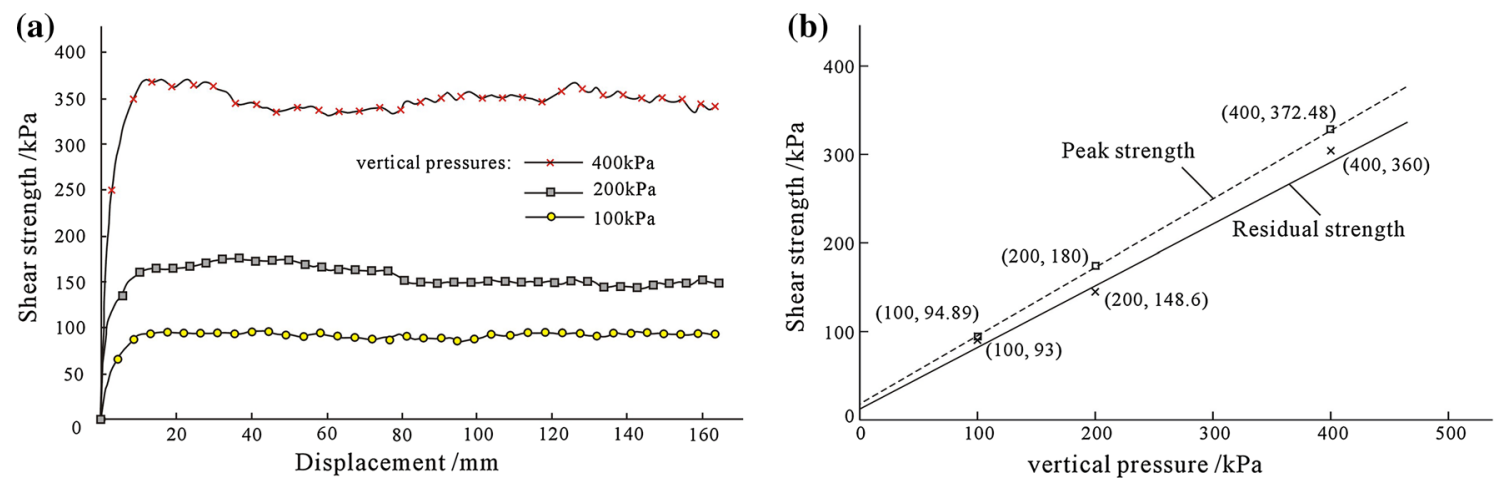

Fig. 7 Shear stress-displacement plots (a) and envelopes of the peak strength and the residual strength (b) for soil samples (S09) taken from the back edge sliding zone

and liquid limit and clay particle quantity (Voight 1973; Olson 1974; Holtz and Kovacs 1985). Samples S01 and S09 exhibited different shear strength due to different grain size distributions.

Since the soil samples were collected from the sliding zone, very low shear strength was expected, especially no or very low cohesion. However, both high peak and residual shear strength were observed. According to the welldocumented data (Voight 1973; Holtz and Kovacs 1985), the upper limit of shear strength usually does not exceed $40^{\circ}$ with the mean value of about $25^{\circ}$. Both peak and residual strength of the back-scarp soil specimen reach this 
limit. The high cohesion might be due to a number of factors: the experiment design and the apparatus configuration. The low confining pressure $(40 \mathrm{kPa})$ and shearing rate might play an important role in the high residual cohesion. Usually, with lower confining pressure and shearing rate, larger residual cohesion is obtained. Nevertheless, for giant landslide, the frictional angle usually dominates its movement while the cohesion usually has a smaller impact.

It is necessary to justify such high shear strength in the pre-existing rupture surface of ancient landslide. Chlorite and illite of low plasticity are the dominant clay minerals in the slip surface (Fig. 5). Holtz and Kovacs (1985) suggested an increasing effective friction angle with lowplasticity materials. A healing mechanism of the rupture surface may also help understand its high shear strength. Stark et al. (2005) presented ring shear test results on two soil specimens with a period of 230 days and suggested that a failure surface which has achieved a drained residual strength condition may undergo "healing" and exhibit a higher strength than the earlier residual value. Carrubba and Del Fabbro (2008) also suggested that the strength along a pre-existing shear surface may increase with time if the sliding mass stops moving and remains stable. The back-calculated shear strength is often greater than the residual strength determined in laboratory. The range of these values seems appropriate to the observed conditions in the large stable deep-seated landslides. Such healing mechanism is plausible to account for its high peak strength and stable status for a long period. This might be able to explain why lots of ancient landslides are dormant.

\section{Liquefaction of the sliding zone soil}

The grain size analysis shows that, although the content of $<0.075 \mathrm{~mm}$ grains of the front edge sliding zone soil is up to $40-60 \%$, the clay content is only $15-25.6 \%$. Especially, the clay minerals consist of only chlorite and illite (Fig. 5), which are small in specific surface area, poor in hydrophilicity, and low in physical-chemical activity. These features are favorable for liquefaction of sliding zone soil under dynamic condition. For the secondary landslide in Luosiwan, the overlying load on the front edge is small and the sliding zone soil is saturated or semisaturated, which also provides favorable conditions for liquefaction of sliding zone soil. Liquefaction is conducive to sliding. Therefore, this is a potential risk in the secondary landslide under study and measures have to be taken to mitigate the risk, such as man-made drainage. In addition, in the Sanjiang region and the Tibetan plateau of China, metamorphic rock slopes containing chlorite and illite are widely distributed. They are very similar to the landslide under study and pose a common problem which shall be stressed and studied. Perhaps this study might provide some references for similar landslides.

Liquefaction of sand, clean or with some fine content, has been extensively studied. For cohesive soils, Perlea (2000) summarized several categories of cohesive soils potentially liquefiable: clayey silts or silty clays of low plasticity, highly sensitive clays, and collapsible loess. The clay minerals in the sliding zone soil of Luosiwan landslide are non-expandable chlorite and illite. They are characterized by low plasticity, low viscosity, poor hydrophilicity, and low physical-chemical activity, which belong to the first category. This helps to understand the high susceptibility to liquefaction for sliding zone soil under dynamic loading.

In the last decade, the role that sliding zone soil, as well as its liquefaction, plays in the development and occurrence of large landslides have been increasingly stressed (Wang et al. 2002, 2007; Hu et al. 2009; Sassa et al. 2004; Zhang et al. 2011a; Rozos et al. 2011, 2013; Mohamed et al. 2013). More importantly, similarly to that observed by $\mathrm{Hu}$ et al. (2009) during ring shear tests on soil of the Yigong long-distance landslide, obvious liquefaction of shear strips are observed in the sample S01. As mentioned above, frequent landslides in the Sanjiang region might be related to such liquefaction to a great extent. The mechanism of liquefaction for such giant landslide needs to be prudently investigated. Two mechanisms exist: (1) sliding displacement triggers excess pore pressure, resulting in liquefaction; (2) The rising pore pressure due to rainfall and water level rising results in liquefaction and then triggers the landslide displacement. Both mechanisms could account for the characteristics of Luosiwan landslide. However, the first mechanism might be more dominant.

Stability analysis of the landslide

Stability analysis is conducted for a particular rupture surface of the reactivated landslide. The shear strength reduction method is a practical approach for determining the factor of safety for slopes (Dawson et al. 1999; Cheng et al. 2007). The failure mechanism of reactivated landslide

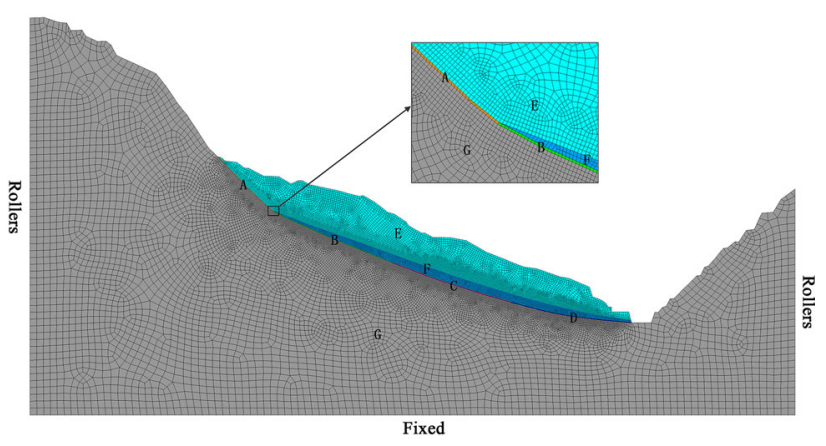

Fig. 8 Finite element model of the landslide 
Table 3 Physical and mechanical parameters of materials for FEM

\begin{tabular}{lllllll}
\hline Material type & Name of material & $\begin{array}{l}\text { Density } \\
\gamma / \mathrm{g} \cdot \mathrm{m}^{-3}\end{array}$ & $\begin{array}{l}\text { Elastic modulus } \\
E / \mathrm{GPa}\end{array}$ & $\begin{array}{l}\text { Poisson's } \\
\text { ratio } v\end{array}$ & $\begin{array}{l}\text { Cohesion } \\
c / \mathrm{KPa}\end{array}$ & $\begin{array}{l}\text { Internal friction } \\
\text { angle } \varphi /^{\circ}\end{array}$ \\
\hline A & Back edge of slip belt & $1834(1940)$ & $0.60(0.55)$ & $0.35(0.36)$ & $13.35(11.65)$ & $34.8(29.0)$ \\
B & Middle-back part of slip belt & $1869(1940)$ & $0.53(0.40)$ & $0.37(0.38)$ & $12.46(10.67)$ & $30.53(22.0)$ \\
C & Middle-front part of slip belt & $1904(1940)$ & $0.47(0.40)$ & $0.37(0.38)$ & $11.56(10.67)$ & $26.27(22.0)$ \\
D & Front edge of slip belt & 1940 & 0.40 & 0.38 & 10.67 & 22.0 \\
E & Slip mass above phreatic line & 1834 & $0.80(0.60)$ & $0.34(0.35)$ & $17.50(13.35)$ & $37.7(34.8)$ \\
F & Slip mass under phreatic line & 1940 & 0.55 & 0.36 & 11.65 & 29.00 \\
G & Bed rock & 2500 & 19.60 & 0.19 & 2000 & 45.00 \\
\hline
\end{tabular}

Data in parentheses are values of the parameters in wet season

(a)

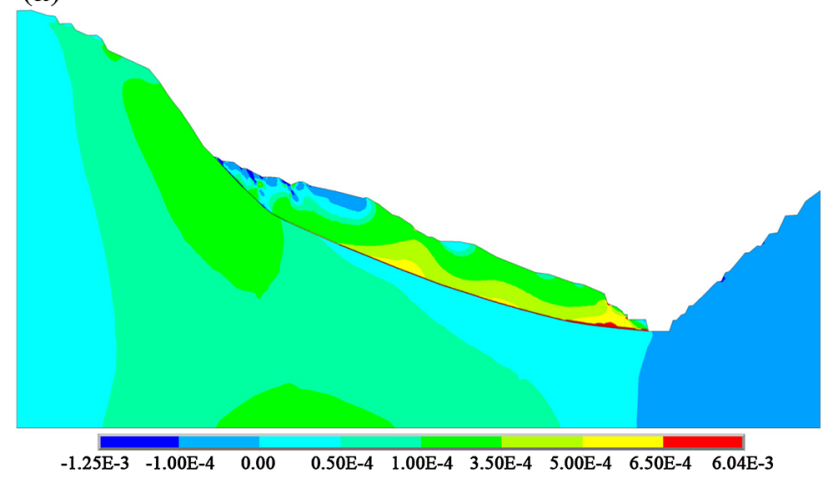

(b)

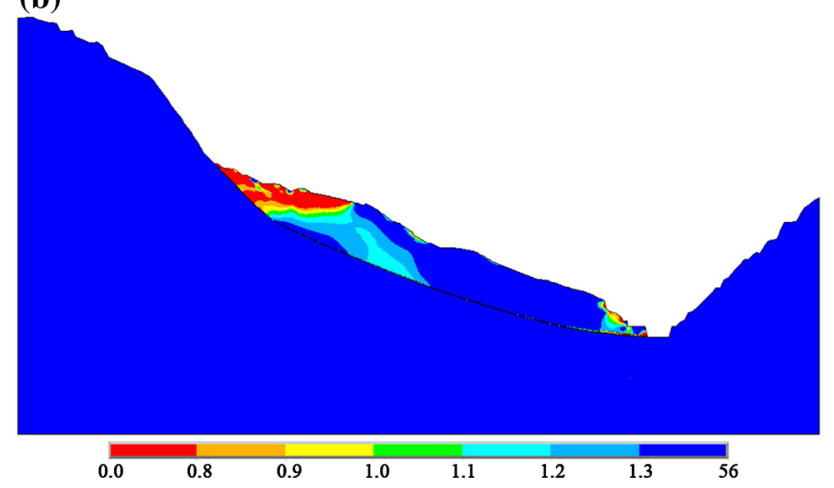

Fig. 9 Modeling results for dry season: a contour of shear strain; b stability coefficient of each node

is examined by finite element modeling (FEM) with strength reduction. The strength parameters of the sliding zone soil may vary in a wide range, which results in large variations in factors of safety (El-Ramly et al. 2002). Generally, the shear strength of sliding zone soil is assumed constant in most numerical simulations on landslide stability. However, field observations and laboratory tests suggest different shear behaviors at different segments of the rupture surface. The stability of the secondary landslide is analyzed by FEM with strength reduction, and different shear strength is applied for different parts of sliding zone. (a)

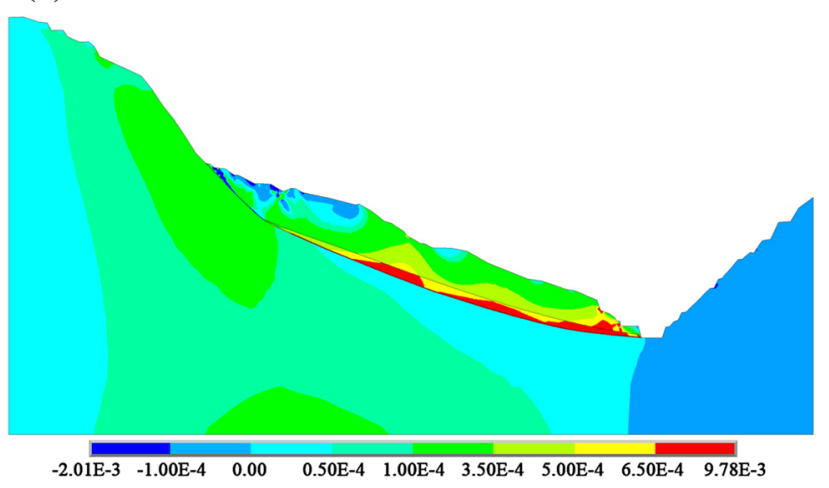

(b)

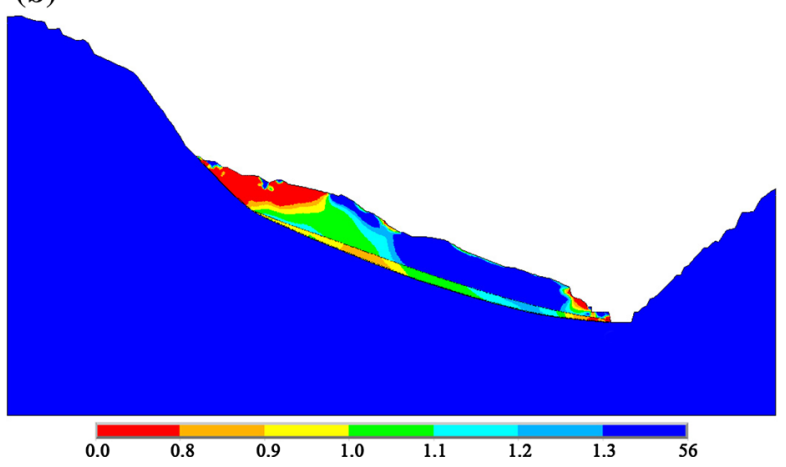

Fig. 10 Modeling results for wet season: a contour of shear strain; b stability coefficient of each node

With shear strength ( $c$ and $\tan \varphi$ ) reduction, the finite element model becomes unstable, and the nodal displacement upon slope failure increases dramatically, compared with that before failure (Dawson et al. 1999). Meanwhile, the corresponding reduction coefficient is determined to be the safety factor of the slope. The Drucker-Prager criterion is adopted.

According to the geological profile (Fig. 3), the secondary landslide can be divided into four parts, namely the sliding zone, the slip mass above/under phreatic surface (E/ F) and bed rock $\mathrm{G}$, among which the sliding zone could be 
further divided into four subparts, namely, the back edge A, the middle-back part $\mathrm{B}$, the middle-front part $\mathrm{C}$ and the front edge D. Various parts were represented by seven types of elasto-plastic geological materials in the finite element model (Fig. 8). The phreatic surface has a large impact on the modeling results. The phreatic surface in the model can be determined by long-term observations in a number of deep wells.

Slope stability in wet season and dry season is considered, with the phreatic surface at the bottom of its back part and at the middle of front edge of slip belt (Fig. 3), respectively. The material parameters, as listed in Table 3, are based on the ring shear test results or the work by $\mathrm{Xu}$ et al. (2006).

In dry season, the overall stability coefficient of the slope is 1.243 , and the plastic shear zones are distributed in the front part (Fig. 9a), which indicates that the slope is stable. The shear strains for three points located at the front part are large, with the maximum value of $6.04 \mathrm{E}-3$, which might be the potential rupture surfaces of the slope toe. This could be further confirmed by the smaller stability coefficients at these locations (Fig. 9b).

In wet season, the slope is in a limit equilibrium state with a stability coefficient of 1.075 . The maximum plastic shear strain reaches $9.75 \mathrm{E}-3$, distributed along the slip belt and the front part (Fig. 10a). Meanwhile, the stability coefficient contour indicates that a small landslide would occur beside G214 Highway (Fig. 10b). In fact, damages were observed in the retaining wall in front of the slope along the Chongjiang River. Compared to the dry season, the area with small stability coefficient expanded from the back part of the sliding mass to the middle part and almost connected with the front part, which indicates that the slope is in a critical state. The area with Fs $1.1-1.3$ is so small that landslide could be triggered at any moment in extremely wet season.

\section{Conclusions}

The reactivation mechanism and stability of ancient landslides are major concerns in the tectonically active zone. It is, however, a complex process involving various factors. Field investigation suggests that the reactivation of ancient giant slide, such as the Luosiwan slide, attribute to the cumulative effect of adverse geological, structural condition and intensive artificial processes. However, long-term observations have shown that the ancient giant slides under study usually remain stable in spite of the adverse tectonic conditions, weak rock mass structure and seasonal climate variation. The subsequent crustal movement, erosion and weathering could make slope less stable but might difficult initiate sliding.
The shear tests indicate high shear strength of the sliding zone soils. The healing mechanism of sliding zone could account for stability of these deep-seated slides due to the large gravity of displace materials exert on it. Landslides may be triggered due to the sudden changes in the forces applied on the slope during engineering construction and excavation. Such sudden changes in strength are more crucial for the deep-seated slide. It can be the cause of a much larger movement of the slope on a deeper surface of rupture.

Both field observation and shear tests suggest that liquefaction might be a major failure mechanism for the reactivation of ancient landslide. From the FEM results for slope stability, the factor of safety is 1.243 in dry season and 1.075 in wet season. It is relatively stable in dry season, while it is in a limit equilibrium state in wet season. A small landslide occurred beside G214 Highway and the locking section of the slip belt is very short. Therefore, this is a potential risk faced by the secondary landslide under study and must be addressed as soon as possible by such measures as man-made drainage.

Acknowledgments This research was supported by the Project of 12th Five-Year National Sci-Tech Support Plan (2011BAK12B09), the Special Project of Basic Work of Science and Technology (2011FY110100-2), the National Natural Science Foundation of China (No. 41072269), and the Project of China Geological Survey (12120113038000). We would like to thank the two anonymous reviewers and the editor for their helpful suggestions, which have improved the clarity of the paper.

\section{References}

American Society for Testing and Materials (1964) Laboratory shear testing of soils. Committee D-18 on Soils for Engineering Purposes, Philadelphia

Bathrellos GD, Gaki-Papanastassiou K, Skilodimou HD, Papanastassiou D, Chousianitis KG (2012) Potential suitability for urban planning and industry development using natural hazard maps and geological-geomorphological parameters. Environ Earth Sci 66:537-548

Bathrellos GD, Gaki-Papanastassiou K, Skilodimou HD, Skianis GA, Chousianitis KG (2013) Assessment of rural community and agricultural development using geomorphological—geological factors and GIS in the Trikala prefecture (Central Greece). Stoch Env Res Risk Assess 27:573-588

Carrubba P, Del-Fabbro M (2008) Laboratory investigation on reactivated residual strength. J Geotech Geoenviron Eng 134:302-315

Cheng Y, Lansivaara T, Wei W (2007) Two-dimensional slope stability analysis by limit equilibrium and strength reduction methods. Comput Geotech 34:137-150

Cruden DM, Varnes DJ (1996) Landslide types and processes. In: Turner AK, Schuster RL (eds) Landslides: investigation and mitigation. U.S. Transportation Research Board, Special Report 247, pp 36-75

Dai F, Wang S, Lee C (1998) The drained residual strength of volcanic derived soil sampled on Lantau island, Hongkong. J Eng Geol 6:223-229 (in Chinese) 
Dai F, Lee C, Deng J, Tham LG (2005) The 1786 earthquake triggered landslide dam and subsequent dam-break flood on the Dadu River, southwestern China. Geomorphology 65:205-221

Dawson EM, Roth WH, Drescher A (1999) Slope stability analysis by strength reduction. Geotechnique 49:835-840

El-Ramly H, Morgenstern NR, Cruden DM (2002) Probabilistic stability analysis for practice. Can Geotech J 39:665-683

Futalan KM, Biscaro JRD, Saturay RM Jr, Catane SG, Amora MS, Villaflor EL (2010) Assessment of potential slope failure sites at Mt. Canabag, Guinsaugon, Philippines, based on stratigraphy and rock strength. Bull Eng Geo Environ 69:517-521

Holtz RD, Kovacs WD (1985) An introduction to geotechnical engineering. Prentice-Hall, pp 543-545

Hu M, Wang F, Cheng Q (2009) Formation of tremendous Yigong landslide based on high-speed shear tests. Chin J Geotech Eng 31:1602-1606 (in Chinese)

Huang R (2009) Some catastrophic landslides since the twentieth century in the southwest of China. Landslides 6:69-81

Hutchinson JN (1988) General report: morphological and geotechnical parameters of landslides in relation to geology and hydrogeology. In: 5th the International Symposium on Landslides. Switzerland Lausanne, pp 3-35

Krahn J, Morgenstern NR (1979) The ultimate frictional resistance of rock discontinuities. Int J Rock Mech Mining Sci 16:127-133

Martel SJ (2004) Mechanics of landslide initiation as a shear fracture phenomenon. Mar Geol 203:319-339

Mohamed AS, Billa Lawal, Pradhan Biswajeet, Mansor Shattri, AlSharif Abubakr AA (2013) Modeling urban growth evolution and land-use changes using GIS based Cellular Automata and SLEUTH models: The case of Sana'a metropolitan city, Yemen. Environ Earth Sci 70:425-437

Olson RE (1974) Shearing strength of kaolinite, illite and montmorillonite. J Geotech Eng Div-ASCE 100(GT11):1215-1299

Papadopoulou-Vrynioti K, Bathrellos GD, Skilodimou HD, Kaviris G, Makropoulos K (2013) Karst collapse susceptibility mapping considering peak ground acceleration in a rapidly growing urban area. Eng Geol 158:77-88

Perlea V (2000) Liquefaction of cohesive soils. Soil Dyn Liq. doi:10. 1061/40520(295)5,58-76

Rozos D, Bathrellos G, Skillodimou HD (2011) Comparison of the implementation of rock engineering system and analytic hierarchy process methods, upon landslide susceptibility mapping, using GIS: a case study from the Eastern Achaia County of Peloponnesus, Greece. Environ Earth Sci 63:49-63

Rozos D, Skilodimou HD, Loupasakis C, Bathrellos GD (2013) Application of the revised universal soil loss equation model on landslide prevention. An example from N. Euboea (Evia) Island, Greece. Environ Earth Sci 70:3255-3266

Sassa K, Fukuoka H, Wang G, Ishikawa N (2004) Undrained dynamic-loading ring-shear apparatus and its application to landslide dynamics. Landslides 1:7-19
Skempton AW (1970) First-time slides in over-consolidated layers. Geotechnique 20:320-324

Skempton AW (1985) Residual strength of clays in landslides, folded strata and the laboratory. Geotechnique 35:3-18

Stark TD, Choi H, McCone S (2005) Drained shear strength parameters for analysis of landslides. J Geotech Geoenviron Eng 131:575-588

Varnes DJ (1978) Slope movement types and processes. In: Schuster RL, Krizek RJ (eds), Landslides: analysis and control. U.S. Transportation Research Board, Special Report, p 176

Voight B (1973) Correlation between Atterberg plasticity limits and residual strength of natural soils. Geotechnique 23:265-267

Wang F, Sassa K, Wang G (2002) Mechanism of a long-runout landslide triggered by the August 1998 Heavy rainfall in Fukushima Prefecture, Japan. Eng Geol 63:169-185

Wang G, Sassa K, Fukuoka H, Tada T (2007) Experimental study on the shearing behavior of saturated silty soils based on ring-shear tests. J Geotech Geoenviron Eng 133:319-333

Weidinger JT (2006) Landslide dams in the high mountains of India, Nepal and China-stability and life span of their dammed lakes. Ital J Eng Geol Environ (special issue) 1:67-80

Xu W, Hu R, Yue Z, Tan R, Li R, Zeng R (2006) Numerical simulation on stability of right bank slope of Longpan in TigerLeaping Gorge area. Chin J Geotech Eng 28:1996-2004 (in Chinese)

Yang Z, Xu Q, Liu Z, Zhao S (2001) The large-scale and high-speed ring-shear test apparatus and application of studying the landslide. J Changchun Univ Sci Technol 31:163-167 (in Chinese)

Youssef AM, Maerz NH (2013) Overview of some geological hazards in the Saudi Arabia. Environ Earth Sci 70:3115-3130

Youssef AM, Pradhan B, Sabtan AA, El-Harbi HM (2012) Coupling of remote sensing data aided with field investigations for geological hazards assessment in Jazan area, Kingdom of Saudi Arabia. Environ Earth Sci 65:119-130

Zhang Y, Zhang J, Lei W (2007) Discussion on environmental geological problems in the areas from Southwest China to Southeast Asia. Earth Sci Front-Engl 14:24-30

Zhang M, Yin Y, Hu R, Wu S, Zhang Y (2011a) Ring shear test for transform mechanism of slide-debris flow. Eng Geol 118:55-62

Zhang Y, Guo C, Qu Y, Song Y (2011b) Engineering geological properties of altered rocks and implications for railway construction in the Sanjiang orogenic belt, Southwest China. Bull Eng Geol Environ 70:143-152

Zhang Y, Zhao X, Lan H, Xiong T (2011c) A Pleistocene landslidedammed lake, Jinsha River, Yunnan, China. Quatern Int 233:72-80 